\title{
Media Pembelajaran Gempytha Sebagai Inovasi Pembelajaran Matematika Di Era Pandemi
}

\author{
Nurmitasari Nurmitasari ${ }^{1)}$, Dika Artha Putri ${ }^{2)}$ \\ Program Studi Pendidikan Matematika, Universitas Muhammadiyah Pringsewu \\ email : nurmitasari@umpri.ac.id ${ }^{11}$,_dika.18030031@student.umpri.ac.id2)
}

\begin{abstract}
Abstrak
Pandemi menyebabkan pembelajaran dilakukan dalam jaingan (daring). Namun pelaksanaan pembelajaran daring selama sebatas memberikan tugas lewat Whatsupp grup sehingga menimbulkan kebosanan. Untuk itu tujuan dari penelitian ini adalah untuk mengembangkan dan menguji kelayakan media pembelajaran berupa game edukasi "GEMPYTHA" (Game Edukasi Matematika Pythagoras) sebagai inovasi pembelajaran matematika di era pandemic. Metode penelitian ini adalah pengembangan (research and development) dengan mengadopsi langkahlangkah Dick and Carey yaitu analisis kebutuhan untuk mengidentifikasi tujuan, analisis instruksional, analisis pembelajar dan konteks, merumuskan tujuan performansi, mengembangkan instrumen penilaian (membuat lembar validasi dan angket respon siswa terhadap media), mengembangkan strategi pembelajaran, memilih materi pembelajaran dan mengembangkan/membuat media, menvalidasi media, merevisi media, mengujicoba media guna melihat respon siswa. Hasil penelitian antaralain (1) hasil validasi oleh tiga validator yang terdiri dari 2 ahli dalam bidang pendidikan matematika dan 1 ahli dalam bidang teknologi informasi diperoleh bahwa media pembelajaran Gempytha dinyatakan valid dengan aspek kriteria penelaah yaitu materi, konstruksi dan bahasa; dan (2) hasil ujicoba media pembelajaran pada yaitu persentase respon siswa terhadap media diperoleh $84,21 \%$ dengan kriteria sangat baik. Berdasarkan hasil penelitian dapat disimpulkan bahwa media pembelajaran media pembelajaran berupa game edukasi "Gemphita" layak digunakan dalam proses pembelajaran matematika secara daringdi era pandemic.
\end{abstract}

Kata kunci: daring, game, Pengembangan Dick and Carey.

\section{PENDAHULUAN}

Hadirnya virus corona di Indonesia tanpa disadari oleh membuat masyarakat untuk menggunakan perkembangan teknologi revolusi 4.0. Seluruh aktivitas dalam dunia pendidikan kini dilakukan dengan cara daring (online) sehingga seluruh warga pendidikan pun harus menyesuaikan keadaan saat ini. Albert (2020:2) menyatakan bahwa pembelajaran daring merupakan pembelajaran yang berlangsung didalam jaringan dimana pengajar dan pelajar tidak bertatap muka secara langsung. Pembelajaran daring membutuhkan bantuan aplikasi tertentu seperti whatsApp, Zoom, google meeting dan lain sebagainya guna menunjang pembelajaran.

Pembelajaran secara daring juga dilaksanakan pada SMP 11 Maret Sumberagung. Kegiatan pembelajaran melalui aplikasi whatsApp. Kedati demikian kegiatan yang berlangsung selama ini untuk hanyalah 
mengirimkan tugas untuk membaca dan mengerjakan soal yang ada diLKS melalui whatsApp grup. Seperti yang tampak pada gambar 1 berikut.

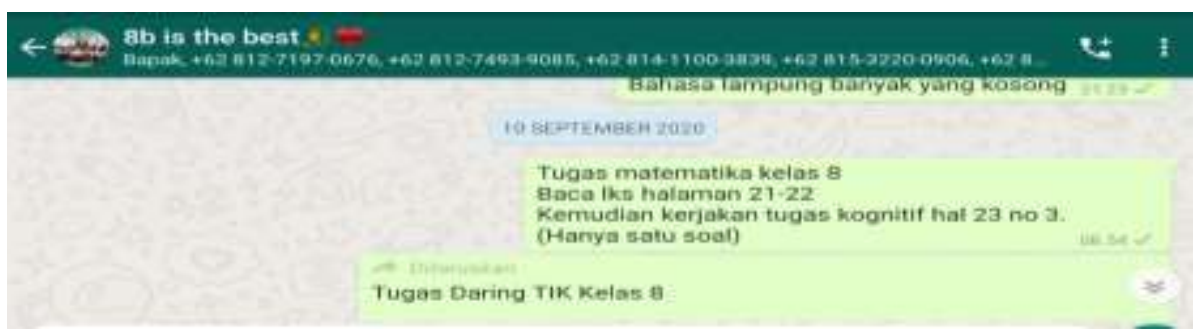

Gambar 1. Kegiatan pembelajaran menggunakan whatsApp grup

Hal ini menimbulkan kebosanan dan kurangnya ketertarikan siswa terhadap proses pembelajaran sehingga siswa merindukan sekolah kembali. Sedangkan pada masa pandemi yang semakin luas penyebarannya untuk tatap muka secara langsung masih belum diperbolehkan. Hal ini membutuhkan solusi, sehingganya siswa merasa senang walaupun belajar di rumah. Salahsatunya membuat media pembelajaran berupa Game Edukasi sebagai inovasi untuk membangkitkan antusias dan keaktifan siswa terhadap proses pembelajaran meskipun saat ini kegiatan belajar mengajar harus dilakukan secara daring. Nunu Mahnun (2012) mengemukakan bahwa pada proses pembelajaran, media pengajaran merupakan wadah atau penyalur pesan dari sumber pesan dalam hal ini guru kepada penerima pesan dalam hal ini siswa. Kemudian Inung Diah Kurniawati dan Sekreningsih Nita (2018) menyatakan bahwa media pembelajaran adalah teknologi pembawa pesan yang dapat dimanfaatkan untuk keperluan pembelajaran. Disimpulkan bahwa media pembelajaran adalah suatu wahana penyalur informasi dalam hal ini materi pembelajaran dari guru kepada siswanya.

Di era pandemi suatu media pembelajaran sangat membantu guru dalam melaksanakan pembelajaran dan membantu siswa untuk lebih mudah memahami materi pembelajaran. Namun media pembelajaran yang monoton tetap akan membuat siswa bosan dalam melihatnya sehingga dibutuhkan media pembelajaran yang interaktif. Media pembelajaran interaktif adalah suatu media yang digunakan dalam pembelajaran dengan proses penggunaannya melibatkan komunikasi dua arah yaitu antara manusia dan medianya. Hal ini selaras Darmawaty Tarigan \& Sahat Siagian (2015) media interaktif digolongkan sebagai media konstruktifistik yang terdiri dari pembelajaran, siswa, dan proses pernbelajaran dengan karakteristik terpenting pada media pembelajaran interaktif adalah bahwa siswa tidak hanya memperhatikan penyajian atau objek, tetapi dipaksa untuk berinteraksi selama mengikuti pelajaran. Kemudian Andizal \& Ahmad Arif (2017) mengemukakan bahwa media pembelajaran yang interaktif adalah media yang memberikan respon kepada penggunanya, baik respon berupa jawaban, pilihan keputusan dan lain - lain serta memberikan tantangan - tantangan tersendiri kepada siswa baik 
berupa latihan ataupun evaluasi yang mendorong siswa untuk menyelesaikannya.

Media memiliki peranan yang sangat penting dalam pembelajaran, terutama dalam pembelajaran daring saat ini. media memiliki beberapa fungsi. Menurut Rika Lisiswanti, Oktadoni Saputra, \& Indri Windarti (2015) media memiliki fungsi, diantaranya yaitu : (1) membangkitkan minat dan motivasi; (2) mengurangi verbalisasi; (3) sebagai penyalur informasi; (4) sebagai gain attention; (5) mengaktifkan mahasiswa pada saat belajar (active learning); (6) memberi dorongan terhadap siswa; (7) meningkatkan retensi pengetahuan dalam pembelajaran.

Media atau multimedia berpengaruh pada pembelajaran active learning (belajar aktif) dimana yang lebih berpengaruh pada active cognitive learning (kognitif) daripada behaviour activity (prilaku). Pembelajaran dengan activeinstructional method (game interaksi dan simulasi) dapat meningkatkan pemahaman terhadap tujuan dan hasil pembelajaran. Disimpulkan bahwa media pembelajaran memiliki peran yang sangat penting dalam proses pembelajaran, dimana media dapat memacu semangat, keaktifan dan daya saing siswa ketika pemilihan media yang digunakan tepat dalam proses pembelajaran dan kebutuhan siswa.

Dalam proses pembelajaran tentu memerlukan media yang diminati oleh para siswa, yang dapat menimbulkan keaktifan, semangat, dan daya saing siswa. game merupakan sebuah inovasi dalam pembelajaran. game sebagai media pembelajaran adalah suatu permainan yang dapat menghibur dan mengandung unsur-unsur pendidikan, yang bertujuan untuk bisa menjadi alat pembelajaran (Wahyu Wibisono \& Lies Yulianto, 2010). Game juga meningkatkan daya saing antar siswa, juga dengan adanya game siswa akan lebih tertarik dan tidak mudah bosan dalam proses pembelajaran. Ketika pembelajaran diselingi dengan game pun siswa akan merasa lebih tertantang. Akan tetapi dalam proses pembelajaran media game harus memenuhi beberapa kriteria, menurut (Wahyu Wibisono \& Lies Yulianto, 2010) game sebagai media pendidikan ini di dalamnya harus memenuhi syarat yang harus dipenuhi diantaranya: (1) isi game harus bersifat mendidik bagi penggunanya; (2) membuat pengguna menjadi berfikir dan terdidik dengan adanya game tersebut; (3) iringan musik yang ada membuat pengguna menjadi terangsang untuk berfikir dan dapat menerima permainan yang dimainkan; (4) tampilan dapat menarik pengguna untuk memainkan game tersebut.

Salah satu materi matematika yang dipelajari pada SMP adalah teorema Pythagoras. Teorema Pythagoras adalah suatu materi yang sangat digunakan untuk mempelajari materi matematika lain pada jenjang yang lebih tinggi baik pada SMP, SMA, maupun pada perguruan tinggi. Untuk itu tujuan dari penelitian ini adalah untuk mengembangkan media pembelajaran matematika yang interaktif berbasis game yang diberi nama Gempytha (Game Edukasi Matematika Pythagoras). Gempytha adalah media pembelajaran interaktif berbasis computer atau android untuk mata pelajaran Pythagoras berupa game yang memuat latihan-latihan soal yang 
memuat materi-materi pembelajaran pythagoras. Media ini memudahkan siswa SMP dalam memahami materi pythagoras. Dalam pythagoras siswa akan mempelajari bentuk umum dari rumus pythagoras, penerapan konsep pythagoras dalam kehidupan sehari-hari, dan tripel pythagoras. Dalam kehidupan sehari-hari banyak menggunakan ilmu pythagoras contohnya tukang bangunan mengukur lahan yang akan dibuat sebuah rumah atau gedung, mengukur panjang dan sudut tangga, dan masih banyak lagi.

Gempytha dirancang untuk diterapkan dengan model pembelajaran kooperatif tipe TGT (Teams Game Tournaments). Model pembelajaran kooperatif adalah salah satu alternative untuk membantu siswa mengacu pada cara pembelajaran yang mana siswa bekerja sama dalam kelompok kecil, saling membantu dalam belajar, anggota kelompok bertanggung jawab atas ketuntasan tugas-tugas kelompok dan untuk mempelajari materi itu sendiri (Nurmitasari, Robia Astuti, \& Sutanti Diah Lestari, 2017). TGT adalah salah satu pembelajaran kooperatif yang menempatkan peserta didik dalam kelompok-kelompok belajar yang beranggotakan 5 sampai 6 orang peserta didik yang memiliki kemampuan, jenis kelamin dan suku atau ras yang berbeda. Dalam proses pembelajaran masing-msaing kelompok akan diuji pemahaman materi dengan game berupa LCC atau lomba cerdas cermat. Dengan demikian penggunaan media pembelajaran interaktif gempytha akan lebih menantang bagi siswa sehingga siswa tertarik dalam mempelajari materi pelajaran yang berdampak pada optimalnya hasil belajar. Untuk itu, perlu diujicobakan untuk mengetahui apakah media gempytha tersebut layak untuk digunakan.

\section{METODELOGI}

Jenis penelitian ini adalah Research and Development (R\&D). Desain penelitian pengembangan ini menggunakan model penelitian dan pengembangan yang diadaptasi dari pengembangan multimedia Dick and Carry. Adapun langkah-langkah Dick and Carey yaitu: (1) analisis kebutuhan untuk mengidentifikasi tujuan, (2) analisis instruksional, (3) analisis pembelajar dan konteks, (4) merumuskan tujuan performansi, (5) mengembangkan instrumen penilaian, (6) mengembangkan strategi pembelajaran, (7) mengembangkan dan memilih materi pembelajaran, (8) melakukan evaluasi formatif, (9) melakukan revisi, (10) merancang dan melakukan evaluasi sumatif. (Yaumil Qoriaha, Sumarno, Nurul Umamah, 2017). Penelitian ini akan dilaksanakan di SMP Sebelas Maret Sumber Agung, Ambarawa Pringsewu dengan subjek penelitian adalah seluruh siswa kelas VIII tahun ajaran 2019-2020 semester ganjil yang berjumlah 19 siswa. Pengumpulan data pada penelitian ini menggunakan angket respon siswa terhadap media meliputi materi/isi pelajaran, format materi ajar, gambar-gambarnya, kegiatan dalam media dan lembar validasi media meliputi validitas isi yang mencakup semua desain media yang dikembangkan pada tahap perancangan yakni dengan kriteria penelaah yaitu aspek materi, aspek konstruksi, dan aspek bahasa. Analisis data yang 
digunakan pada penelitian ini adalah menggunakan persentase. Dengan kriteria deskripsi persentase kelayakan terlihat pada Tabel 1.

Tabel 1. Kriteria deskriptif persentase kelayakan

\begin{tabular}{cc}
\hline Interval (\%) & Kriteria \\
\hline $81-100$ & Sangat Layak \\
$61-80$ & Layak \\
$41-60$ & Cukup Layak \\
$21-40$ & Kurang Layak \\
$0-20$ & Tidak Layak \\
\hline
\end{tabular}

(Heriyanto et al., 2014)

\section{HASIL DAN PEMBAHASAN}

Produk yang dihasilkan dalam pengembangan ini berupa media pembelajaran interaktif Gempytha (Game Edukasi Pythagoras). Adapun langkah-langkah dalam mengembangkan media Gempytha mengikuti prosedur pengembangan model Dick and Carrey sebagai berikut.

\section{Analisis Kebutuhan Untuk Mengidentifikasi Tujuan}

Pada tanggal 7 Maret 2020 melakukan observasi di SMP 11 Maret Sumberagung, Kecamatan Ambarawa, Kabupaten Pringsewu. Berdasarkan hasil wawancara dengan siswa yang bernama Fibry Sintia P dan Abdul Rohim dan guru matematika yang bernama Heri Kuswanto, M.Pd diperoleh data sulitnya memahami konsep pythagoras Selanjutnya berdasarkan hasil observasi diperoleh data bahwa dalam dalam pembelajaran guru belum menggunakan alat bantu berupa media pembelajaran yang dapat membantu siswa dalam memahami konsep dari materi teorema Pythagoras. Disimpulkan bahwa kebutuhan siswa dan guru pada mata pelajaran matematika di SMP Sebelas Maret Sumbera Agung yaitu penggunaaan media pembelajaran matematika interaktif berbasis ICT pada materi Teorema Pythagoras, dengan tujuan agar siswa mampu memahami konsep dan penerapan Teorema Pythagoras.

\section{Analisis Instruksional;}

Dari hasil wawancara diperoleh data bahwa yang menjadi kebutuhan dalam peroses pembelajaran adalah kesiapan siswa dan kesiapan dari guru. Kesiapan siswa berupa motivasi dalam diri dan kesiapan guru adalah kesiapan materi dan alat bantu untuk menyampaikan materi Teorema Phytagoras yaitu berupa media pembelajaran interaktif. Beberapa yang harus dicapai oleh siswa yaitu (a) kompetensi dasar, menjelaskan dan membuktikan teorema Pythagoras dan tripel Pythagoras; dan menyelesaikan masalah yang berkaitan dengan teorema Pythagoras dan tripel Pythagoras. (b) Indikator, menemukan Teorema Pythagoras; menyatakan Teorema Pythagoras dalam bentuk rumus; menyatakan apakah tigas bilangan yang diberikan merupakan tripel Pythagoras; 
menghitung panjang sisi ketiga segitiga siku-siku; memecahkan masalah pada bangun datar yang berkaitan dengan Teorema Pythagoras. (c) Tujuan Pembelajaran, siswa dapat menemukan Teorema Pythagoras; siswa dapat menyatakan teorema Pythagoras; siswa dapat menyatakan apakah tiga bilangan yang diberikan merupakan Tripel Pythagoras; siswa dapat menghitung panjang sisi ketiga segitiga siku-siku jika dua sisi diketahui; siswa dapat memecahkan masalah pada bangun datar yang berkaitan dengan Teorema Pythagoras.

\section{Analisis Pembelajar dan Konteks}

Kemampuan siswa dalam memahami konsep dasar teorema Pythagoras masih sangat kurang, karena siswa mengandalkan kemampuan mengingat atau menghapal bukan memahami atau menerapkan.

\section{Merumuskan Tujuan Performansi}

Tujuan dari media pembelajaran yang dirancang adalah membantu guru dalam menyampaikan materi pembelajaran Matematika terkhusus pada materi Terema Pythagoras agar materi yang disajikan dapat lebih menarik dan memotivasi siswa dalam mempelajarinya sehingga konsep dapat dipahami oleh siswa dengan mudah.

\section{Mengembangkan Instrumen Penilaian}

Instrument penilaian untuk menilai desain media pembelajarannya berupa lembar validasi dan angket respon siswa. Adapun lembar validasi media pembelajaran interaktif Gempytha ada pada Tabel 2.

Tabel 2. Lembar Validasi Media Pembelajaran Interaktif Gempytha

\begin{tabular}{|c|c|c|}
\hline \multirow[t]{2}{*}{ No } & \multirow[t]{2}{*}{ Kriteria Penelaaahan } & Media pembelajajan \\
\hline & & Sesuai Keterangan/Saran \\
\hline \multicolumn{3}{|c|}{ Aspek Materi } \\
\hline 1 & $\begin{array}{l}\text { Isi media telah sesuai dengan materi yang akan } \\
\text { diajarkan; }\end{array}$ & \\
\hline 2 & Materi sesuai dengan tujuan pembelajaran & \\
\hline 3 & $\begin{array}{l}\text { Materi sesuai dengan kompetensi dasar } \\
\text { danindikator pada kurikulum yang berlaku. }\end{array}$ & \\
\hline \multicolumn{3}{|c|}{ Aspek Konstruksi } \\
\hline 4 & Media telah sesuai dengan kebutuhan siswa & \\
\hline 5 & $\begin{array}{l}\text { Media mudah dipahami dan digunakan oleh } \\
\text { siswa }\end{array}$ & \\
\hline 6 & $\begin{array}{l}\text { Media sangat menarik sesuai dengan } \\
\text { perkembangan kognitif siswa }\end{array}$ & \\
\hline 7 & $\begin{array}{l}\text { Media sesuai dengan keadaan sarana dan } \\
\text { prasarana sekolah maupun individu siswa }\end{array}$ & \\
\hline \multicolumn{3}{|c|}{ Aspek Bahasa } \\
\hline 8 & $\begin{array}{l}\text { Kalimat didalam media menggunakan bahasa } \\
\text { yang baku, baik, dan benar }\end{array}$ & \\
\hline 9 & $\begin{array}{l}\text { Kalimat didalam media disusun secara jelas } \\
\text { dan dapat dipahami dengan baik dan mudah } \\
\text { oleh siswa }\end{array}$ & \\
\hline
\end{tabular}


Instrumen angket respon siswa digunakan untuk mengetahui bagaimana respon siwa terhadap penggunaan media pembelajaran interaktif gempytha. Angket respon siswaa mengunakan skala likert dengan rentang 1-4 yang memiliki ketentuan $4=$ Sangat Baik, $3=$ Baik, $2=$ Cukup, 1 = Tidak Baik. Untuk angket respon siswa ada pada tabel 3 .

Tabel 3. Angket Respon Siswa Terhadap Media Pembelajaran Gempytha

\begin{tabular}{|c|c|c|}
\hline No & \multirow[t]{2}{*}{ Pernyataan } & Skor \\
\hline & & 123 \\
\hline 1. & $\begin{array}{l}\text { Penyajian materi dalam media sistematis dan berurutan sehingga } \\
\text { mudah saya pahami }\end{array}$ & \\
\hline 2. & $\begin{array}{l}\text { Media pembelajaran Pythagorasku memudahkan saya dalam } \\
\text { belajar }\end{array}$ & \\
\hline 3. & $\begin{array}{l}\text { Dengan adanya media Pythagorasku ini menambahkan minat } \\
\text { saya untuk belajar matematika materi Pythagoras }\end{array}$ & \\
\hline 4. & $\begin{array}{l}\text { Media Pythagorasku ini dapat menjadi media pembelajaran } \\
\text { Matematika mandiri bagi saya }\end{array}$ & \\
\hline 5. & $\begin{array}{l}\text { Permasalahan dan persoalan yang disajikan dalam media } \\
\text { Pythagorasku merangsang rasa ingin tahu saya }\end{array}$ & \\
\hline 6. & $\begin{array}{l}\text { Bagi saya belajar Matematika (Pythagoras) menggunakan Media } \\
\text { Pythagorasku ini mengasyikkan }\end{array}$ & \\
\hline 7. & $\begin{array}{l}\text { Permasalahan yang disajikan meningkatkan keaktifan saya } \\
\text { dalam proses pembelajaran }\end{array}$ & \\
\hline 8. & $\begin{array}{l}\text { Kemampuan pemecahan masalah dapat membentuk sikap ilmiah } \\
\text { saya }\end{array}$ & \\
\hline 9. & Penyajian Media Pythagorasku menarik & \\
\hline 10. & Alur ceritanya yang disajikan sesuai taraf berfikir saya & \\
\hline 11. & $\begin{array}{l}\text { Kejelasan alur cerita yang menarik dan mengarah pada } \\
\text { pemahaman konsep saya }\end{array}$ & \\
\hline 12. & $\begin{array}{l}\text { Tingkat artistik dan estetika (keunikan) dalam media menarik } \\
\text { sehingga saya termotivasi untuk belajar }\end{array}$ & \\
\hline 13. & $\begin{array}{l}\text { Tingkat interaktivitas media menyenangkan dan memikat saya } \\
\text { dalam belajar }\end{array}$ & \\
\hline
\end{tabular}

Mengembangkan Stategi Pembelajaran

Media pembelajaran didesain mengunakan strategi pembelajaran TGT (Teams Games Tournament) yang didalamnya mengkombinasikan antara proses pembelajaran dengan menggunakan permainan atau game.

Mengembangkan dan Memilih Materi Pembelajaran

Materi Pembelajaran yang digunakan untuk media pembelajaran Gempytha adalah Teorema Pythagoras. Berikut tampilan dari beberapa slide hasil pengembangan media pembelajaran gempytha. 


\section{Media Pembelajaran Gempytha}

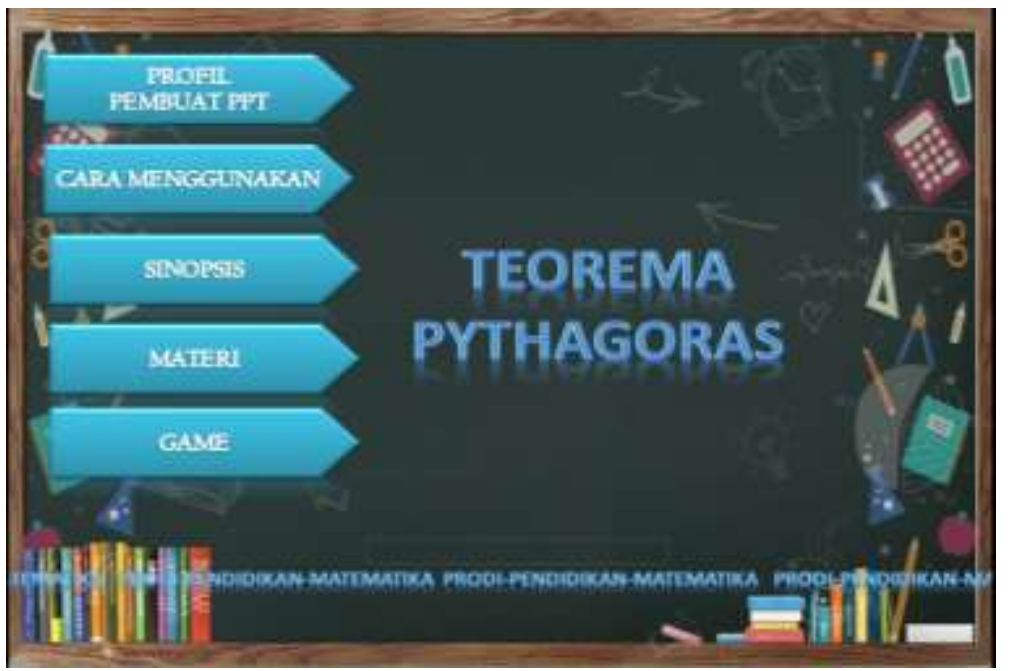

Gambar 2. Tampilan Beranda Media

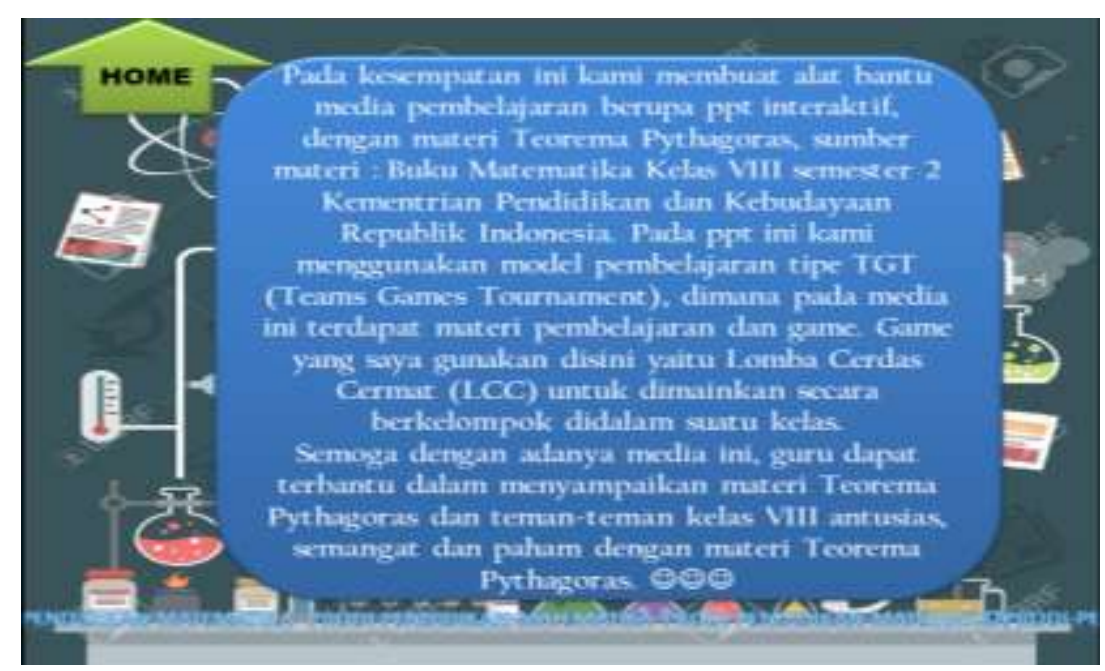

Gambar 3. Tampilan synopsis

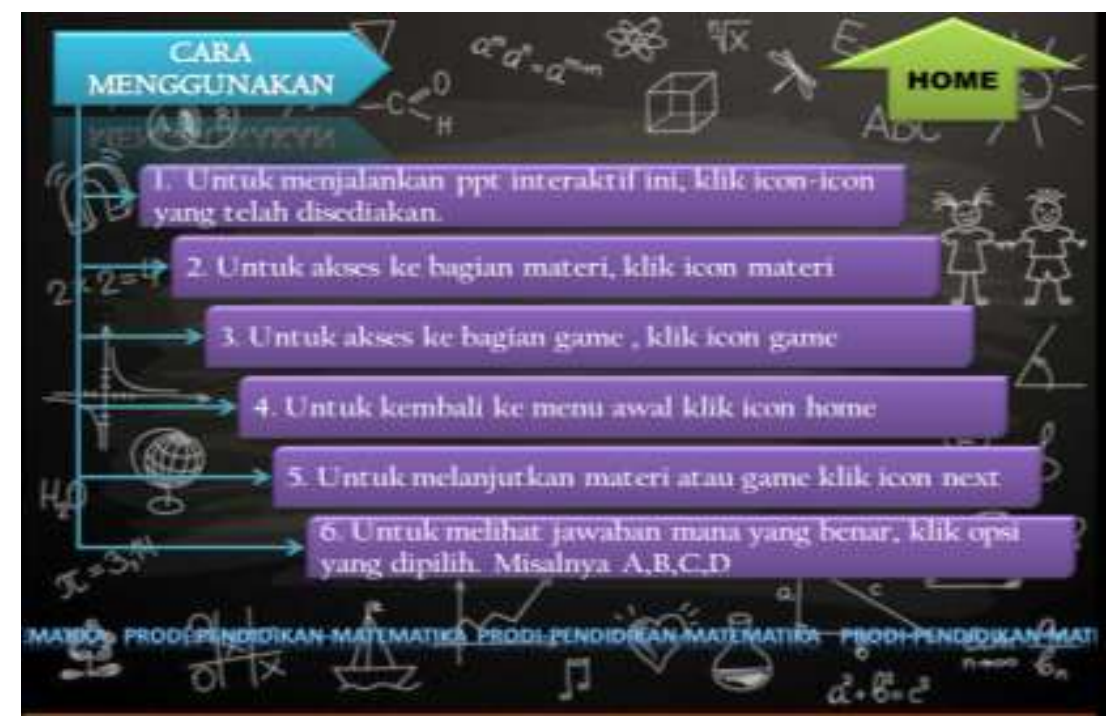


Gambar 5. Tampilan petunjuk

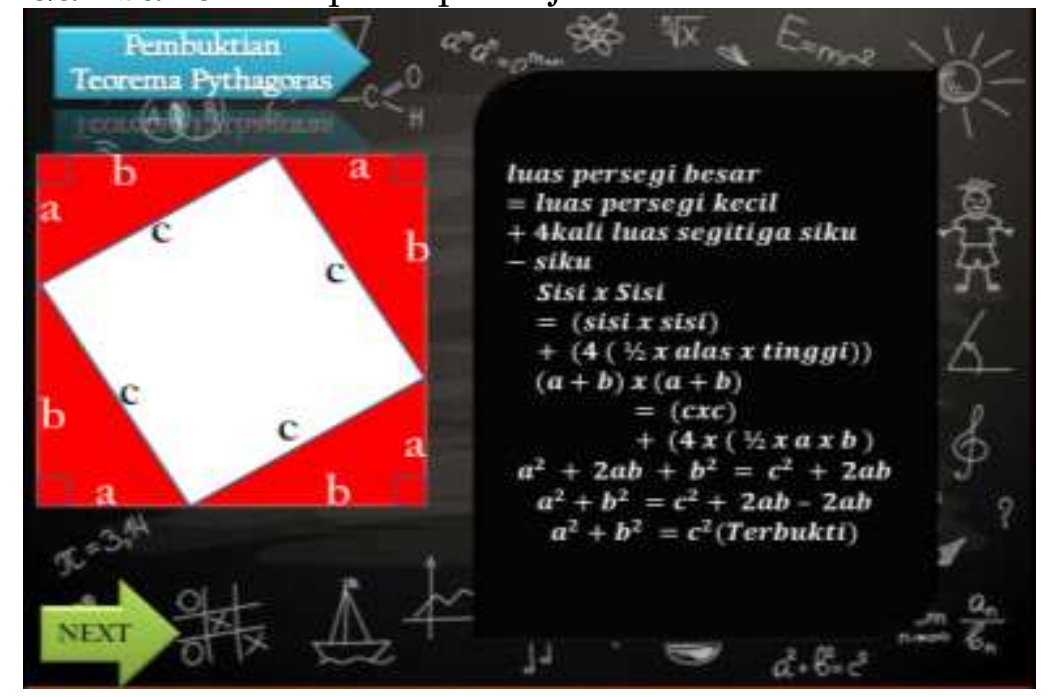

Gambar 6. Tampilan salah satu materi

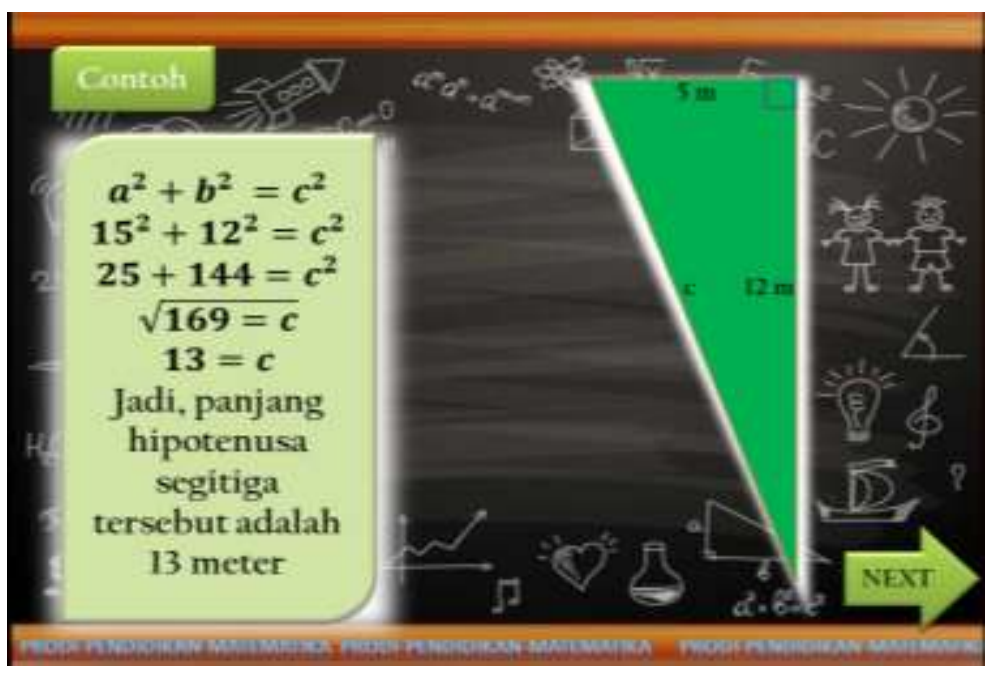

Gambar 7. Tampilan contoh soal

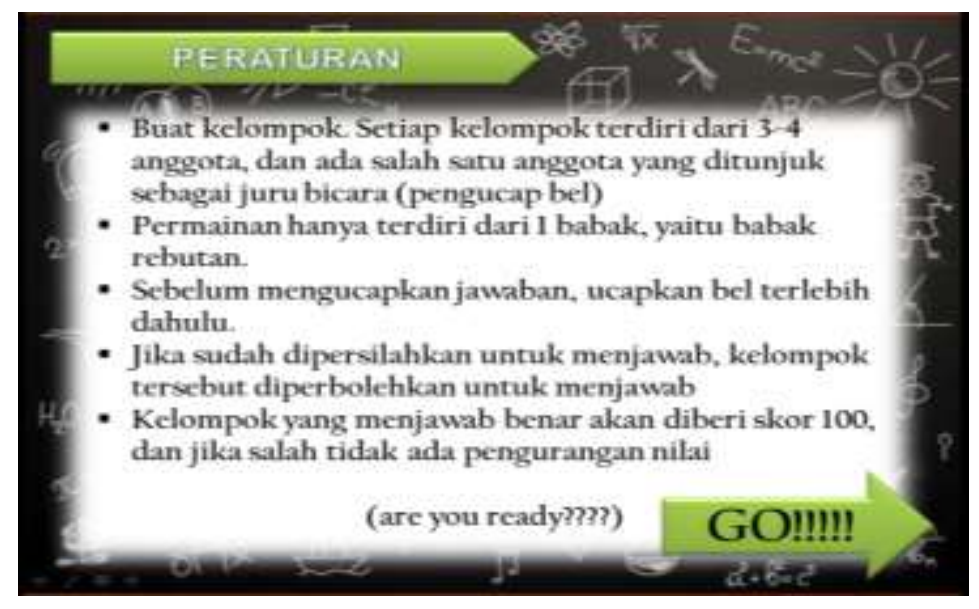


Gambar 8. Tampilan petunjuk bermain game

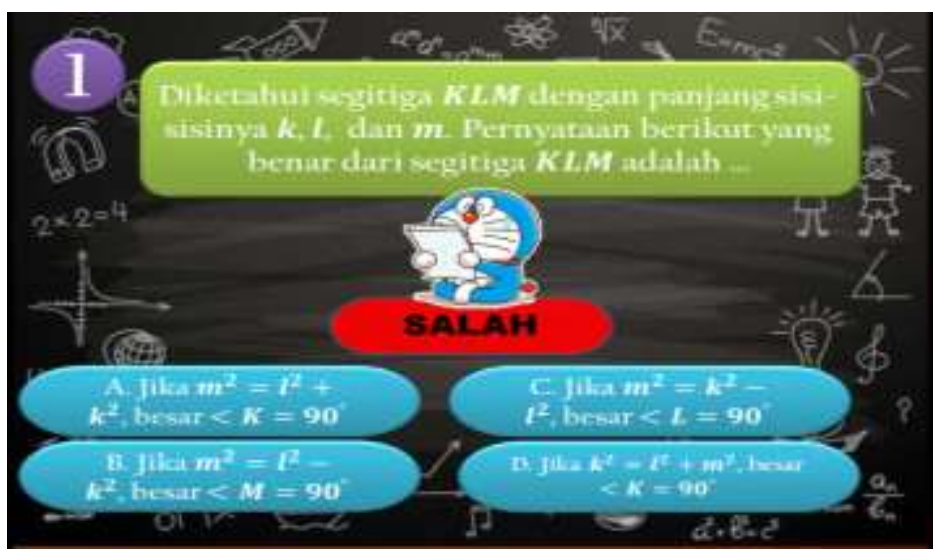

Gambar 9. Tampilan game jawaban salah

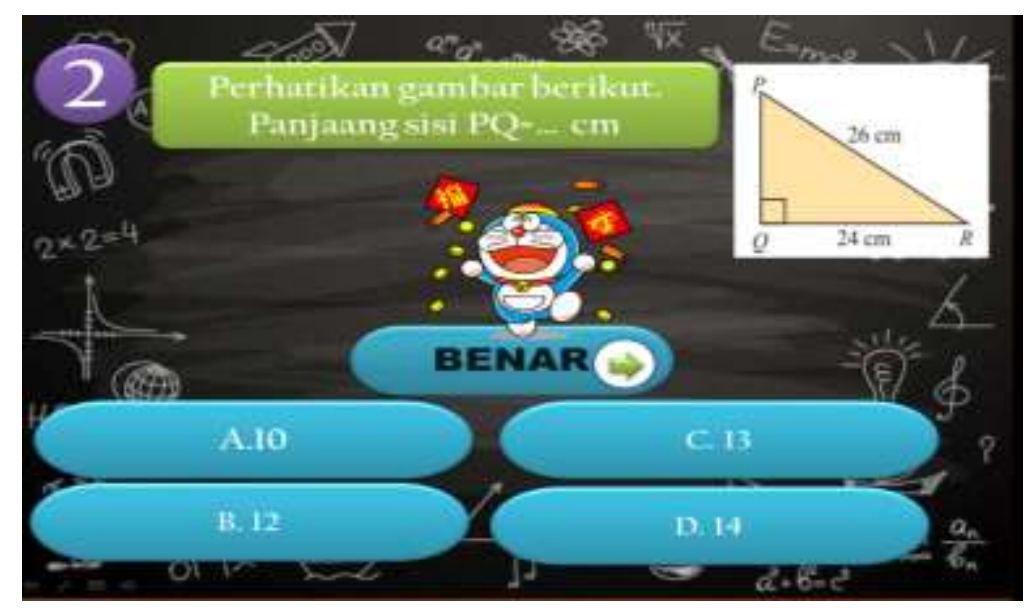

Gambar 10. Tampilan game jawaban benar

\section{Melakukan Evaluasi Formatif}

Media pembelajaran interaktif Gempytha di validasi oleh 3 orang ahli yaitu Heri Kuswanto, M.Pd selaku guru matematika kelas VIII; Nanda Aditya, S.Kom selaku ahli ICT; Ari Suningsih, M.pd selaku dosen program studi matematika. Hasil validasi dari validator pertama yaitu Heri Kuswanto, M.Pd adalah media pembelajaran interaktif Gempytha sesuai dengan kriteria penilaian, dengan saran yaitu harap mengurangi gambargambar sebagi penarik, karena jika terlalu banyak bisa memecahkan konsentrasi siswa terhadap materi. Hasil validasi dari validator kedua yaitu Nanda Aditya, S.Kom adalah media pembelajaran interaktif Gempytha sesuai dengan kriteria penilaian, dengan saran yaitu mungkin dibberapa slide yang menampilkan banyak teks, sebaknya menggunakan background yang lebih casual (tidak terlalu banyak gambar). Hasil validasi dari validator ketiga yaitu Ari Suning, M.Pd adalah media pembelajaran interaktif Gempytha sesuai dengan kriteria penilaian. Berdasarkan hasil validasi dari ketiga validator disimpulkan bahwa media pembelajaran interaktif Gempytha valid dan layak untuk digunakan. 


\section{Melakukan Revisi}

Berdasarkan saran yang diperoleh dari validator maka media pembelajaran direvisi sesuai dengan saran yang diberikan yaitu mengubah background menjadi yang lebih casual dan mengurangi gambar yang terlalu banyak pada slide. Setelah direvisi media pembelajaran gempytha di implementasikan kepada siswa kelas VIII di SMP Sebelas Maret Sumberagung guna mengetahui respon siswa terhadap media tersebut.

\section{Merancang dan Melakukan Evaluasi Sumatif}

Berdasarkan hasil dari angket Respon Siswa Terhadap Media Pembelajaran Gempytha diperoleh data bahwa proporsi siwa yang memilih kriteria sangat baik ada 16 siswa, kriteria siwa yang memilih baik adalah 3 siswa. Berdasarkan hasil analisis data maka diperoleh bahwa persentase respon siswa dengan kriteria sangat baik adalah $84,21 \%$ dan persentase respon siswa dengan kriteria baik adalah 15,79\%. Dengan hasil ini menunjukkan bahwa media pembelajaran gempytha sangat layak untuk digunakan. Sejalan dengan hasil penelitian ((Iis Erawati \& Totok Sukardiyono, 2017) yaitu media pembelajaran interaktif pada mata pelajaran Administrasi Server materi proxy server dapat dikategorikan sangat layak. untuk menurut penilaian dari ahli media dan ahli materi serta pengguna, masing -masing memberi skor penilaian $85,50 \%$ dari ahli media, 85,83\% dari ahli materi dan 85,73\% dari pengguna. Skor tersebut masuk dalam kategori sangat layak. Sehingga media ini siap dan sangat layak digunakan untuk pembelajaran pada mata pelajaran Administrasi server. Hal ini memperlihatkan bahwa media pembelajaran interaktif sangat layak untuk digunakan dalam pembelajaran. Hasil ini selaras dengan hasil pengembangan media pembelajaran interaktif yaitu dilihat dari validasi ahli dan respon siswa media pembelajaran interaktif gempytha layak untuk digunakan.

Gempytha (Game Edukasi Matematika Pythagoras) merupakan media pembelajaran interaktif berbasis computer atau android untuk mata pelajaran Pythagoras berupa game yang memuat latihan-latihan soal. (Andizal \& Ahmad Arif, 2017) mengemukakan bahwa media pembelajaran yang interaktif adalah media yang memberikan respon kepada penggunanya Adanya interaksi ini yang akan membuat pembelajaran lebih bermakna dan tujuan pembelajaran dapat tercapai secara optimal.

\section{SIMPULAN}

Berdasarkan analisis dan pembahasan maka disimpulkan bahwa media pembelajaran interaktif Gempytha dikembangkan dengan mengadopsi langkah-langkah pengembangan dick \& carey. Namun ada sedikit modifikasi dari langkah-langkah tersebut dikarenakan hanya ingin melihat kelayakan dari media tersebut. Adapun langkah-langkah pengembangan media yaitu: analisis kebutuhan untuk mengidentifikasi 
tujuan, analisis instruksional, analisis pembelajar dan konteks, merumuskan tujuan performansi, mengembangkan instrumen penilaian (membuat lembar validasi dan angket respon siswa terhadap media), mengembangkan strategi pembelajaran, memilih materi pembelajaran dan mengembangkan/membuat media, menvalidasi media, merevisi media, mengujicoba media guna melihat respon siswa.

Berdasarkan hasil validari dari 3 validator yaitu 2 validator ahli pada bidang matematika dan 1 validator yang ahli pada bidang ICT dinyatakan bahwa media pembelajaran interaktif Gempytha layak untuk digunakan. Kemudian media pembelajaran interaktif Gempytha diimplementasikan kepada siswa untuk mengetahui respon siswa terhadap media pembelajaran interaktif Gempytha. Adapun respon siswa terhadap media pembelajaran interaktif Gempytha sangat baik.

\section{REFERENCES}

Albert Efendi Pohan (2020). Konsep Pembelajaran Daring berbasis pendekatan Ilmiah. Jawa Tengah: CV Sarnu Untung.

A Heriyanto , S Haryani, SMR Sedyawati (2014). Pengembangan Multimedia Pembelajaran Interaktif Berbasis Education Game Sebagai Media Pembelajaran Kimia. Jurnal Chemistry in education (CiE). Vol. 3. No. 1

Andizal dan Ahmad Arif ( 2017). Pengembangan Media Pembelajaran Interaktif Pada Sistem E-Learning Universitas Negeri Padang. Jurnal Inovasi, Vokasional dan Teknologi (INVOTEK), Vol. 17. No. 2.

Darmawaty Tarigan dan Sahat Siagian ( 2015). Pengembangan Media Pembelajaran Interaktif Pada Pembelajaran Ekonomi. Jurnal Teknologi Informasi \& Komunikasi dalam Pendidikan. Vol. 2. No. 2.

Iis Erawati \& Totok Sukardiyono (2017). Uji Kelayakan Media Pembelajaran Interaktif Pada Mata Pelajaran Administrasi Server. Jurnal Electronics, Informatics, and Vocational Education (Elinvo). Vol. 2. No.2

Inung Diah Kurniawati dan Sekreningsih Nita (2018). Media Pembelajaran Berbasis Multimedia Interaktif untuk Meningkatkan Pemahaman Konsep Mahasiswa. Journal of Computer and Information Technologi. Vol.1. No. 2.

Nunu Mahnun ( 2012). Media Pembelajaran (Kajian terhadap Langkahlangkah Pemilihan Media dan Implementasinya. Jurnal Pemikiran Islam. Vol. 37. No. 1 
Nurmitasari, Robia Astuti, \& Sutanti Diah Lestari (2017). Eksperimentasi Model Pembelajaran Cooperative Script Pada Pembelajaran Matematika. Jurnal Eksponen,. Vol 7 No 2.

Rika Lisiswanti Oktadoni Saputra \& Indri Windarti (2015). Peranan Media Dalam Pembelajaran. Jurnal Kesehatan. Vol VI, No. 1

Wahyu Wibisono, Lies Yulianto (2010). Perancangan Game Edukasi Untuk Media Pembelajaran Pada Sekolah Menengah Pertama Persatuan Guru Republik Indonesia Gondang Kecamatan Nawangan Kabupaten Pacitan. Journal Sentra Penelitian Engineering dan Edukasi (Speed ). Vol. 2. No. 2

Yaumil Qoriaha, Sumarno, Nurul Umamah (2017). The Development Prehistoric Of Jember Tourism Module Using Dick And Carey Model. Jurnal Historica. Vol. 1. No. 1 